\title{
RETURNS TO EDUCATION AND WAGE DISTRIBUTION IN INDONESIA: A COMPARISON ACROSS GENDER GROUPS
}

\author{
Weni Lidya Sukma ${ }^{1}$, Kadir ${ }^{2}$ \\ ${ }^{1}$ Universitas Indonesia, Faculty of Economics and Business, Jl. Prof. Dr. Sumitro \\ Djojohadikusumo, Kota Depok 16424 \\ ${ }^{2}$ Statistics Indonesia (BPS), Jl. Dr. Sutomo 6-8, Jakarta 10710 \\ 1wenilidya@bps.go.id \\ ${ }^{2}$ kadirsst@bps.go.id
}

\begin{abstract}
This study is aimed to estimate the returns to education in Indonesia not only at the mean but also across the whole distribution by implementing quantile regression techniques and doing a comparison between gender groups. It also relates the estimation results to the two channels through which education affects the wages inequality, i.e., between-and within-educational-levels earning differentials. We found that education has a positive and significant impact on wage distribution implying that increasing the level of education could shift the wages distribution to the right. In general, the estimates of the returns to education for the female is higher than male. For each gender group, our study also confirms the presence of both the between-groups wages inequality associated with the difference in educational levels among individuals and the within-groups wages inequality caused by the difference in ability among individuals in the same level of education. Our findings suggest that promoting the same level of education for all, particularly tertiary education, could bring down the wages inequality although at the same time the inequality may still exist due to the difference in unobserved characteristic among individuals at the same level of education.
\end{abstract}

Keyword: returns to education, wages inequality, gender, quantile regression.

Abstraksi. Penelitian ini bertujuan untuk mengestimasi dampak pendidikan terhadap upah (returns to education) di Indonesia, bukan hanya rata-rata tapi juga gambaran pada keseluruhan distribusi upah dengan menerapkan regresi kuantil dan melakukan perbandingan antar kelompok gender. Penelitian ini juga merelasikan hasil estimasi dengan dua saluran yang melalui keduanya pendidikan memengaruhi ketimpangan upah, yaitu perbedaan upah antar individu antar tingkat pendidikan yang berbeda dan perbedaan upah antar individu di dalam kelompok pendidikan yang sama. Kami menemukan bahwa pendidikan berdampak positif dan signifikan terhadap distribusi upah yang menunjukkan bahwa peningkatan level pendidikan akan menggeser distribusi upah ke sisi kanan. Secara umum, estimasi dampak positif pendidikan lebih tinggi pada kelompok perempuan dibanding laki-laki. Pada setiap kelompok gender, penelitian kami mengkonfirmasi eksistensi ketimpangan upah antar tingkat pendidikan dan di dalam level pendidikan yang sama akibat perbedaan kemampuan antar individu. Temuan kami menyarankan bahwa mendorong tingkat pendidikan yang sama untuk semua masyarakat, khususnya pendidikan tinggi, dapat mengurangi ketimpangan upah meski pada saat yang sama ketimpangan tetap eksis sebagai akibat perbedaan dalam karakteristik yang tidak teramati antar individu pada tingkat pendidikan yang sama.

Kata kunci: returns to education, ketimpangan upah, gender, regresi kuantil. 


\section{INTRODUCTION}

Income inequality is one of the main issues in Indonesian development. Although it has been declining in recent years, the level is still considered above that is expected. The Gini ratio, an indicator of income inequality, was 0.39 in 2017 (BPS, 2018). Inequality is a critical issue for Indonesia since it can reduce economic growth and the power of the growth in reducing poverty, which is another primary issue in Indonesian development. Moreover, many studies have shown that there is a strong relationship between inequality and violent conflict due to the weakening of social cohesion in society.

One of the primary sources of income inequality is wages inequality, which is closely related to the distribution of earnings among employees. Lee and Wie (2015) pointed out that wages inequality in Indonesia has experienced a widening gap since 2003. In this regard, information about the underlying factors causing the wage inequality in Indonesia is essential for the policymakers to reduce inequality in society.

There is a strong belief that improving the level of education in society could reduce wage inequality (Andini, 2017). Plenty of empirical research showed that the impact of education on (log) earnings, which is called as returns to education, is positive and statistically significant (Pereira and Martins, 2004; Salehatin and Ebru, 2011; Purnastuti et al., 2013; Marcos 2016; and Andhini 2017). Suryahadi et al. (2018) found that around 80 per cent of the increase in inequality in Indonesia during the period 1992-2011 is caused by changes in the structural factors including levels of education. They also pointed out that investment in education is one of the critical measures for Indonesia to bring down inequality, although it will only make impacts in the medium term.

Those findings are strong evidence that, on average, more education implies higher earnings as a result of shifting in the earnings distribution to the right. In other words, a policy that promotes a tertiary education for all individuals in society could be a promising mean to bring down the wages inequality.

In the case of Indonesia, there are plenty of studies on the relationship between education and earnings. Deolaliker (1993), who used data from the 1987 National Socio-Economic Survey (Susenas) and the 1986 Village Potential Survey (Podes), found that the returns to education range from around 10 per cent for workers with some primary education to around 20 per cent for workers with secondary or higher education.

Using the data from the 2004 National Labour Force Survey (Sakernas), Comola and Mello (2010) pointed out that the estimate of the returns to education range from 9.5 per cent to 11.28 per cent by applying several methods (OLS, HeckmanSelections, and regression with instrumental variables). One of the more recent studies is Purnastuti, Miller, and Salim (2013) focusing on the development of the returns to education in Indonesia between 1993 and 20072008. They found that although the returns to education generally declined during this period, they are still positive and statistically significant for all educational levels. Meanwhile, using a multiple-year data (1993, 1997, 2000 
and 2007) from the Indonesia Family Life Survey (IFLS), Newhouse and Suryadarma (2011) compared the returns to vocational and general secondary education in Indonesia. They pointed out that there is no significant difference in the rate of returns between vocational and general schooling.

All studies highlighted above only focused on the impact of education on the mean of the earnings distribution. In other words, they assumed that the returns to education are the same throughout the wages distribution. However, the possible differences regarding the impact of education along the different points of the wages distribution may be necessary, especially for policy purposes. Studies that took into account this issue are Patrinos, Ridao-Cano, and Sakellarion (2006,2009). Using quantile regression, they found that Indonesia showed only a modest difference (about 10 per cent) in the impact of education on earnings at the 90th percentile and the 10th percentile. The more recent study is Widyanti (2018) that applied quantile regression on the Sakernas data for the period 2008 and 2015.

To the best of our knowledge, studies focusing on the relationship between wages inequality and returns to education in Indonesia are very limited. As highlighted earlier, most of the studies regarding returns to education in Indonesia only emphasised the estimation of the magnitude of the returns and its development across time and ignored its impacts on the wage distribution. As mentioned earlier, the more recent study assessing the relationship between wages inequality and the returns to education is Widyanti (2018). She found that education increases the wages inequality through the increasing of the wage dispersion within the same educational level due to the significant variation in the rate of the returns to education in different quantiles for the same level of schooling. However, her study only focused on the pooled sample and ignored a comparison across gender. To fill this gap, our study trays to provide a broader picture by doing comparison across gender groups.

Our research is aimed to enrich studies about the returns to education in Indonesia. It main contribution is to present a broader picture regarding the returns to education and its relationship with the wages distribution. Besides estimating the rate of the returns to education, this research also relates it with the two channels through which education affects the wages inequality, i.e., between-and within-educationallevels earning differentials. Also, this research also makes a cross-gender comparison to provide a worthwhile insight into understanding the relationship between education and wage distribution in Indonesia.

The plan of the paper is as follows. Section 2 describes the methodology, i.e., the conceptual framework and data used. This section gives a brief explanation of the model specifications implemented and the key variables included in the models. In section 3, we present a descriptive analysis and discuss the estimation results of the models focusing on some key findings. Section 4 contains the conclusion of the study. Tables of estimation results are presented in the Appendix. 


\section{METHODOLOGY}

\section{Conceptual frame work}

As mentioned earlier, this study is not only restricted to the relationship between education and wages. To enrich our analysis, besides estimating the rate of returns to education, this study also examines the relationship between the former variable and the wage distribution in shaping the wages inequality.

There are three channels through which education can affect wages distribution and wages inequality (Pereira and Martin, 2004): between-educational-levels earning differentials, within-educational-levels earning differentials and changes in the distribution of schooling. This research will focus on the first two channels. The first channel affects the so-called betweengroups wage inequality through the differences in mean earning associated with the difference in educational levels among individuals. Through this channel, the wages inequality can be reduced by pursuing a policy that promotes the same level of education (college education), which is so-called "tertiary education for all", for each in society (Andhini, 2017).

The second channel influences the within-groups wage-inequality. It has to do with the degree of dispersion of earnings among employees at each level of education. The source of the withineducational-level wages differentials is unobserved characteristics such as innate and abilities (Andhini, 2017). Through this channel, increasing in education implies higher wages inequality as captured in some studies, among others, Widyanti (2018), Andhini (2017) and Marcos (2016).

To examine the relationship between the returns to education and the wages distribution satisfactory, in particular, within-levels wages distribution, we apply a quantile regression on the Mincerian model. In this regard, we follow previous research, among others, Buchinsky (1994), Mueller (1998), Pereira and Martin (2004), Montenegro (2001), Harman et al. (2003), and Gardezable and Ugidos (2005).

A quantile regression can provide snapshots of different points of conditional distribution of wages (Pereira and Martin, 2004) and enable us to gauge the different degree of dispersion of earnings at each educational level. By applying quantile regressions, we can estimate the impact of education not only at the mean but also on the shape of the wages distribution. In other words, the returns to education can be estimated across quantiles of the conditional wage distribution. By doing so, the two channels through which education affects the wages inequality can be analysed comprehensively.

In this research, we extend the classical model proposed by Mincer (1974) by adding some variables, which are also considered to explain the variations in $(\log )$ earnings, other than the standard variables (education and experience). All variables used in the model are explained briefly in Appendix Table 1. The use of these additional variables, which can be considered as post-education decisions, brings down the magnitude of the education coefficient in the model. However, the main motivation of using them is to avoid the omitted variables bias in estimating the model coefficients, particularly the rate of the returns to education. 
The Mincerian model used in this study is given by equation (1) below

$$
\begin{gathered}
\ln w_{i}=x_{i} \beta_{\theta}+u_{i \theta} \\
\text { Quant }_{\theta}\left(\ln w_{i} \mid x_{i}\right)=x_{i} \beta_{\theta}
\end{gathered}
$$$$
\text { with }
$$

where $\ln w_{i}$ is the log of earnings, $x_{i}$ is a vector of exogenous variables, and $\beta_{\theta}$ is the vector of parameters. Quant ${ }_{\theta}\left(\ln w_{i} \mid x_{i}\right)$ denotes the $\theta$ th conditional quantile of $\ln w_{i} \mid x_{i}$. The $\theta$ th regression quantile is ranged $0<\theta<1$ and is defined as the solution of the problem

$$
\min _{\beta \in R^{k}} \sum_{i} \rho_{\theta}\left(\ln w_{i}-x_{i} \beta_{\theta}\right)
$$

where $\rho_{\theta}(\varepsilon)$ is the check function defined as $\rho_{\theta}(\varepsilon)=\theta \varepsilon$ if $\varepsilon \geq 0$ or $\rho_{\theta}(\varepsilon)=$ $(\theta-1) \varepsilon$ if $\varepsilon<0$. This problem can not be solved by linear programming method since it does not have an explicit form. Moreover, the bootstrap methods are applied to estimate the standard errors. In addition, in this research, the Mincerian model is also estimated by OLS as a benchmark. In making a comparison, the model (1) is estimated for different gender groups (male and female)

Some research showed that spatial variables (regional specific effects) such as the minimum regional wages (Rijkers and Waxman, 2017) have significant effects on the wages distribution. To take into account these effects, we also include the provinces dummy variables in the model specification. Moreover, in dealing with the heterogeneity in the residuals of the model, we robastify the standard errors by applying VCE robust standard errors.

The primary focus of this study is to estimate the $\beta_{\theta}$ coefficients that are associated with the education variables. In this research, we use two types of educational variables, i.e., years of schooling (continuous variables) and the educational levels (dummy variables) consisting of nine levels of education, namely no schooling as the reference group, primary school, junior high school, senior high school, diploma, undergraduate, master degree, and doctoral degree.

The use of the dummy variables allows the effects of education on earnings to vary at each educational levels. It is essential to take into account the possibility that the returns to an extra year of education are not identical across levels of education as highlighted in many studies, among others, Psacharopoulos (1985, 1994), Hartog et al. (2001), and Trostel (2003). The inclusion of spline years of education at different levels of education enables us to estimate the returns to education at each level.

From the estimated coefficients of educational variables, the rate of returns to education for each educational level can be obtained in two ways. First, following Deolaliker (1993), the formula for the average rate of the return to education is given by

$$
r_{k}=\frac{\beta_{k}}{n_{k}}
$$

where $\beta_{k}$ is the level of education and $n_{k}$ is the number of years required to complete the level. The main shortcoming of this formula is it can be sensitive to the earnings position of the excluded education group. To avoid this issue, in this research, we can apply the formula proposed by Sakellariou (2003), El-Hamidi (2005), and Kimenyi, Mwabu and Manda (2006) below 


$$
r_{k}=\frac{\left(\beta_{k}-\beta_{k-1}\right)}{\Delta n_{k}}
$$

where $\Delta n_{k}$ is the difference in the years of schooling between education levels $k$ and $k-1$. The last formula focuses on the marginal return. In addition, we also calculate the impact of education on the wages dispersion by computing the difference in the estimated coefficient of $\beta_{k}$ for different quantiles $\left(\mathrm{q}_{9}-\mathrm{q}_{1}\right)$.

The sample selection bias is one of the concerns in this study since wages are only observed for people who participate in the labour force (Jann, 2008). Ideally, this selection bias is corrected with the inverse Mills Ratio proposed by Heckman (1979). However, due to the limited information that explains the labour-force participation, we can not apply this procedure so that the problem is not resolved. Another limitation of this study is the issue of endogeneity on education variable that may arise since this variable is correlated with other unobservable characteristics such as ability and the quality of schooling. Ideally, the regression with instrumental variables should be applied to address this issue. Therefore, the endogeneity bias in the estimated coefficients of educational variables may exist.

\section{Data Source}

This study analyses data from the National Labour Force Survey (Sakernas) conducted by BPS-Statistics Indonesia in August 2016. The survey was started in 1986 and regularly conducted every year to capture the conditions of employment in Indonesia. By the year 2005 and so on, it is carried out twice a year in February and August.

In August 2016, the Sakernas covered 50,000 households scattered in urban and rural areas in 34 provinces. One of the survey's advantages is the richness of employment information provided and its ability to present estimation results from national to provincial levels.

The labour theory approach used in the survey since 1984 is the Standard Labor Force Concept as outlined in the 13th International Conference of Labor Statistician (ICLS) 1982. In the Sakernas, the working population is defined as working-age population (15 years and above) conducting economic activities with the intention of obtaining or assisting in obtaining income or profits, at least one hour (without breaking up) during the past week.

This study focuses only on paid employees (wage earners) consisting of 36,399 individuals $(24,176$ of males and 12,163 of females). The primary variables in this study are wages and education. Wage refers to the wage/salary received by an individual during the past month from the primary job in the form of money or goods. The primary job relates to the industry that provides the most substantial income in a month.

Education in this research is represented by the years of schooling and the level of education attained by the individual. Information about years of schooling is not available. Therefore, it is approached with the highest educational attainment that is converted into years of schooling.

Due to the limited information available, work experience used in this research is potential work experience measured using the approach: age, minus years of schooling, minus six years. The use of potential work 
experience potentially leads to an upward bias in the measurement of work experience for women. This condition could arise because of the issue of career interruption that is common in women mainly because of childbirth and childrearing. For tenure, potential bias is overcome by including its squared term.

\section{RESULTS AND DISCUSSION \\ Educational attainment}

Although the education development in Indonesia has achieved remarkable progress in recent years, the most significant portion of paid employees only attained, at maximum, senior high school. The portion of paid employees, which are either having no school or only attaining primary school, made up about a quarter of the total paid employees. Most of them are concentrated in the low-skilled and lowpaid sectors such as agriculture. Based on our calculation, the paid employee attained tertiary education (diploma and university) only accounted for 23 per cent of the total paid employees in August 2016. This shows that there is still plenty of room for policy makers to narrow the wages inequality by promoting a policy that increases the proportion of population attaining tertiary education.

Figure 1 highlights the difference in terms of educational attainment across gender groups. It can be seen that in general, female paid employees is better than their male counterparts. The proportion of female paid employees that attaining tertiary education was about 28 per cent, which is much higher than that of males paid employee (about 13 per cent). Moreover, we can see that in each gender group the biggest portion of paid employees were workers without tertiary education, mainly no schooling/primary and secondary schooling.

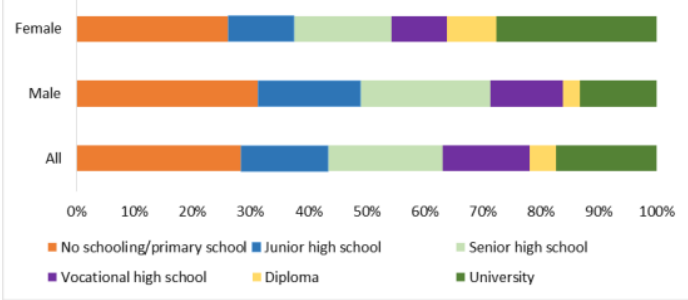

Source: Sakernas (authors calculation)

Figure 1. Educational attainment by gender, August 2016

\section{Wages distribution}

It is well known that the distribution of wages is not symmetric and rightskewed instead. This fact is also confirmed by Figure 2, which present the kernel density of the wages distribution across the levels of education. It can be seen that the distribution of wages among the paid employees exhibits a heavy right-tailed distribution for each level of education. It suggests that the wages inequality exists among individuals at each educational level due to some unobservable characteristics. However, the wages distribution tend to slightly better as the level of education increases. It is evident that the earnings distribution of tertiary education is more equal than that of the wages distribution for lower educational levels.

The figure also confirms the presence of wage inequality across the educational levels. We can see that there is a strong positive link between the wages and the levels of schooling where the higher level of education attained implies the more substantial earnings. It means that increases in educational attainment can shift the earnings 
distribution to the right and brings up the mean of the wages. In other words, pursuing a policy that promotes higher education level, particularly tertiary education (diploma and university), for all individuals in society can be considered as a promising measure to bring down the wages inequality.

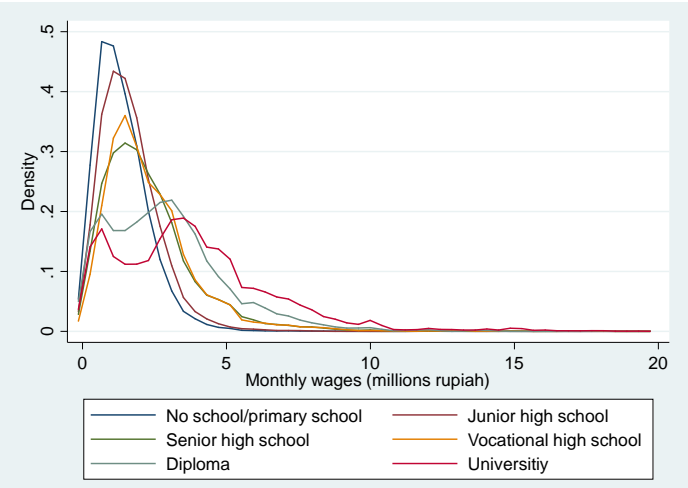

Figure 2. Wage distribution by education level

Source: Sakernas (authors calculation; bandwidth $=0.25$; only the wages of less than 20 million included)

Figure 3 highlights the wages differentials by gender among the paid employees. It confirms that the gender wages gap is a factor in explaining the wages inequality in Indonesia. On average, the female paid employees earned lower wages than that of the male paid employees. This fact suggests that reducing the gender wages gap can bring down wages inequality. It can be done through a policy that can shift the female wage distribution to the right by either eliminating gender discrimination in the workplace or increasing the capability of female workers. Some studies have pointed out the presence of gender wages discrimination in Indonesia, among others Sohn (2015) and Sukma and Kadir (2018). Moreover, the last measure can be done by promoting a tertiary education for all females. In this regard, investment in education and human capital at large that focuses on females can play a determinant role.

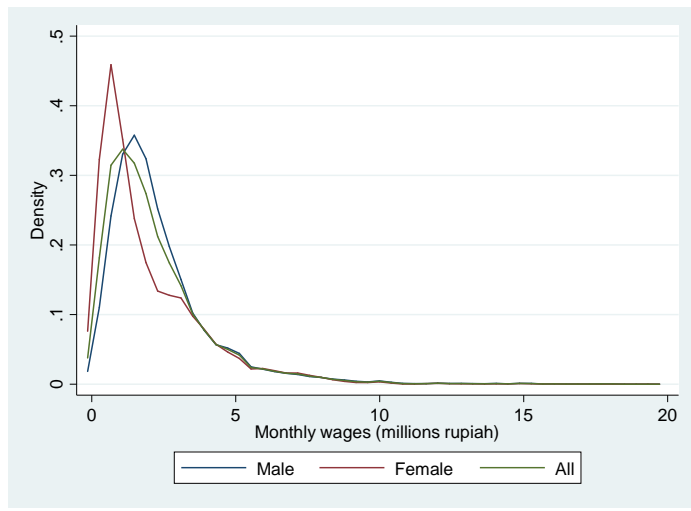

Figure 3. Wage distribution by gender

Source: Sakernas (authors calculation; bandwidth $=0.25$; only the wages of less than 20 million included)

The differences in educational attainment between males and females as presented earlier could explain this gender wages gap. It may indicate that the returns to education are not the same across gender at each education level. Figures 3 also shows that the wages inequality exists at each gender group indicated by the wages distribution that has a heavy right tail for each gender group.

\section{Returns to education}

The estimates of the wages return to education presented in Figure 4 and Appendix Table 3 reveals some interesting findings. The rate of returns is obtained by regressing the years of schooling on the monthly wages in the logarithmic term. Therefore, the estimated coefficient of education variable can be interpreted as a percentage increase in monthly wages due to a one year increase in education. It can be seen that the returns to education are positive (and also 
statistically significant at the 5 per cent level as presented in Appendix Table 3) meaning that more education implies higher earnings. The OLS estimate shows that on average, the monthly wages of paid employees will increase by about 3.7 per cent for every one year increase in years of schooling. Moreover, estimation results from quantile regressions point out that the rate of wages returns to education vary across the (log) earning quantiles, which suggests a positive contribution of education upon within-levels wage inequality.

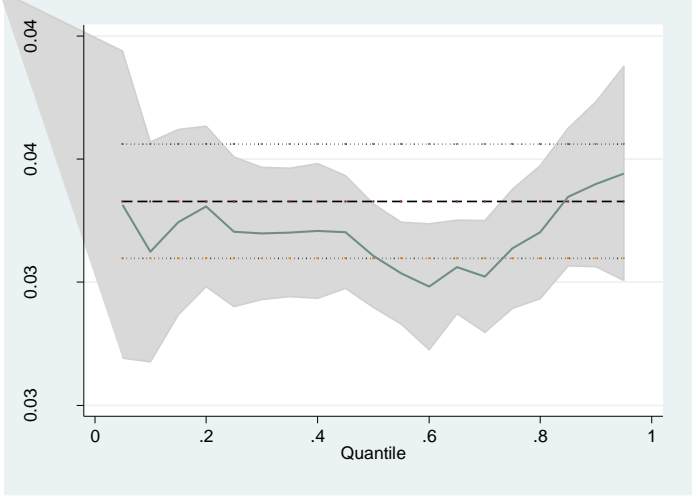

Figure 4. Estimations of Returns to education across wages distribution for pooled sample

Source: authors calculation

Our findings that the effects of education are not the same throughout the wages distribution confirms that education is not independent of other unobserved factors such as ability and other skills relevant to the labour market as founded by Pereira and Martins (2004) for sixteen European countries and Patrinos et al. (2006). Our estimations are smaller than Widyanti's finding using the 2015 Sakernas data. She found that the returns to education in Indonesia range from 5.7 per cent to 7.3 per cent. These substantial differences may arise as she used not only paid employees samples but also the workers as a whole including self- employed workers. Another factor is the model specification. As mentioned earlier in our model we used a significant number of additional variables to avoid omitted variable bias that possible can bring down the magnitude of education coefficient substantially. In general, a higher quantile implies moderately higher returns. However, the difference in returns at the upper and lower level of the earnings distribution is modest, which is only about 0.4 percentage points. In other words, the difference in the impact of education on earnings at the 90th percentile and the 10th percentile is around 12 per cent.

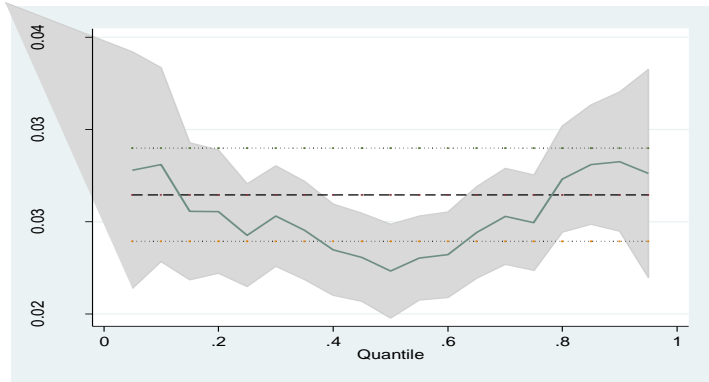

Figure 5. Estimations of Returns to education across wages distribution for male sample

Source: authors calculation

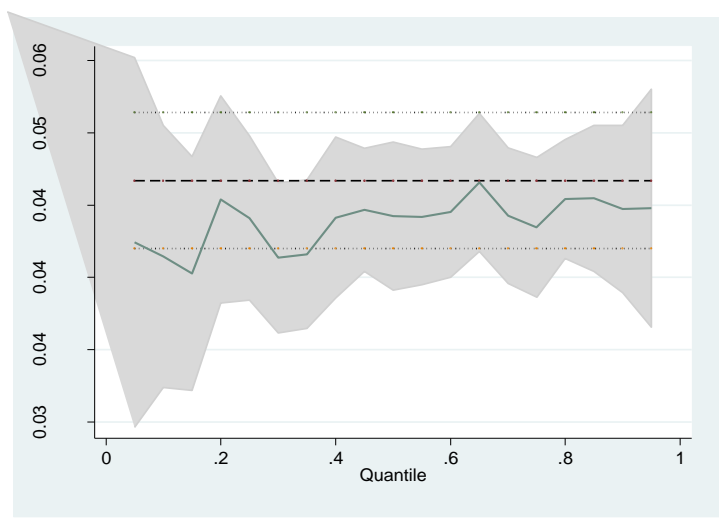

Figure 6. Estimations of Returns to education across wages distribution for female sample

Source: authors calculation 
The wages return to education also vary across gender groups. In general, lower quantiles are only moderately

associated with lower returns to education, especially for the female paid employees. The OLS estimates show that on average the returns to education for the female paid employees is around 4.9 per cent which is much larger than the returns for the male paid employees (3.1 per cent). These findings suggest that improving females education can be a way for the policymakers to narrow the gender wages gap in Indonesia, which is about 30 per cent based on our estimation (see Appendix Table 5). Moreover, for each gender group, the magnitude of the impacts of education on earnings is not the same at each quantile, which again shows both a positive contribution of education upon withinlevels wage inequality and the dependence of education of unobserved skill represent variables. The wages return to education for the female paid employees range from 4 per cent to 5 per cent, while for the male paid employees the returns vary from 2.2 per cent to 3.1 per cent.

However, the difference in returns between for individuals at the 90th quantile and the 10th quantile relatively small for each gender group, especially for the female paid employees. Moreover, for the female paid employees, the rate of return at 10th quantile is the highest, which suggests that education could compensate for low skill.

The estimation results of the model with the level of education as the independent variables, which are presented in Appendix Table 4, point out the strong evidence of the between-groups wage inequality. This finding is consistent with Widyanti (2018) finding. The estimates of the returns to education presented in Appendix Table 2 show that the returns to an extra year of education are not identical across levels of education. In general, the higher the level of education, the higher of earning received by individuals. These findings are consistent for both the pooled sample and each gender group. Again, the finding confirms that a policy promoting a tertiary education for all individuals in society could reduce between-groups inequality.

Moreover, our research also confirms the presence of the within-groups wageinequality due to a dispersion of earnings among employees at each level of education both for the pooled sample and partial sample by gender groups. This finding is also consistent with Widyanti (2018). The estimation results summarized in Appendix Table 2 point out that the rate of the returns to education varies across the wages distribution in each level of education. However, the degree of dispersion could be considered moderate. The existence of this within-groups wage-inequality indicates the presence of the difference in unobserved characteristics such as ability and innate among individuals in the same level of education.

\section{CONCLUSION}

The objective of our research is to estimate the rate of the returns to education in Indonesia not only at the mean but also across the wages distribution. In doing so, we applied the quantile regression techniques on the well-known mincer equation. We then relate our estimation results with the two channels through which education affects the wages inequality, i.e., between-and within-educational-levels 
earning differentials. One thing that can be considered as the novelty of this research is the comparison between the gender groups: male dan female.

We found that education has a positive and significant impact on earnings distribution not only at the mean but also across the whole distribution. An increase in years of schooling can shift the (mean of) wage distribution to the right. In other words, the higher the level of education, the higher of wages earned by an employee. This finding supports the argument that a policy promoting a tertiary education for all can lower the wages inequality. Our findings are consistent for both the whole pooled and each gender group. However, in general, the rate of the returns to education are higher for the female employee than that of male employee suggesting that advancing the women's educational attainment can reduce the wages inequality.

We also found the presence of both the between-groups and within-groups wages-inequality. The two channels through which education affects the wages inequality exist in each gender group. The finding suggests that promoting the same lavel of education for all does not automatically reduce the wages inequality when the difference in such unobserved characteristics exist among individuals in the same level of education. However, our finding pointed out that the degree of dispersion of the returns to education in each level of education is not substantial.

\section{REFERENCES}

Andhini, Corrado.(2017). Tertiary Education for All and Wage Inequality: Policy Insights from Quantile Regression (IZA Policy Paper No.132). Retrieved from: http://ftp.iza.org/pp132.pdf

Badan Pusat Statistik (BPS). (2018, July 16). Tingkat Ketimpangan Pengeluaran Penduduk Indonesia Maret 2018 [Press release]. Retrieved from Badan Pusat Statistik website: https://www.bps.go.id/pressrelease/2018/07/16/1483/persentasependuduk-miskin-maret-2018-turun-menjadi-9-82-persen.html

Comola, M., \& de Mello, L. (2010). Educational attainment and selection into the labour market: the determinants of employment and earnings in Indonesia (Paris-Jourdan Sciences Economiques Working Paper 2010-06). Retrieved from Paris-Jourdan Sciences Economiques website: http://www.pse.ens.fr

Deolalikar, A.B. (1993). Gender differences in the returns to schooling and in school enrollment rates in Indonesia. The Journal of Human Resources 28 (4). 899-932.

El-Hamidi, F. (2005). General or vocational? Evidence on school choice, returns, and "sheep skin" effects from Egypt 1998, presented at the Twenty-Fifth Annual Meeting of The Middle East Economic Associatio, 2005. Philadelphia: Allied Social Sciences Association.

Gardezable, J. \& Ugidos, A. (2005). Gender wage discrimination at quantiles. J. Popul. Econ. 18. 165-179 
Hallward-Driemeier, Mary, Rijkers, B. \& Waxman, A. (2017). Can Minimum Wages Close the Gender Wage Gaps. Review of Income and Wealth. 63(2). 310-334.

Harmon, C., Oosterbeek, H. \&Walker, I. (2003). The returns to education: microeconomics. J. Econ. Surv. 17(2). 115-155.

Hartog, Joop, Pedro T. Pereira, \& José AC Vieira. (2001). Changing returns to education in Portugal during the 1980s and early 1990s: OLS and quantile regression estimators. Applied Economics 33 (8). 1021-1037.

Heckman, J.J. (1979). Sample selection bias as a specification error. Econometrica 47 (1): 153-61.

Jahn, B. (2008). The Blinder-Oaxaca decomposition for linear regression model. Stata Journal 8( 4). 453-479.

Kimenyi, M.S., Mwabu, G. \& Manda, D.K. (2006). Human capital externalities and private returns to education in Kenya. Eastern Economic Journal 32 (3). 493-513.

Lee, J. W., \& Wie, D. (2015). Technological Change, Skill Demand, and Wage Inequality: Evidence from Indonesia. World Development. 67. 238-250.

Marcos, Ines de. (2016). Does Education Reduce Wage Inequality? A Quantile Regression Analysis in Argentina: 2005-2015 (Master's thesis, George Town University). Retrieved from George Town University website: https://repository.library.georgetown.edu

Mincer, J. (1974). Schoolings, Experience, and Earnings. New York: Columbia University Press.

Montenegro, C. (2001). Wage distribution in Chile: does gender matter? A quantile regression approach (Policy Research Report on Gender and Development Working Paper Series 2). Retrieved from the World Bank website: http://siteresources.worldbank.org/INTGENDER/Resources/wp20.pdf.

Mueller, R. (1998). Public-private sector wage differentials in Canada: evidence from quantile regressions. Econ. Lett. 60(2). 229-235.

Newhouse, D. \& Suryadarma, D. (2011). The value of vocational education: high school type and labor market outcomes in Indonesia. The World Bank Economic Review 25 (2).296-322.

Patrinos, H.A., Ridao-Cano, C. \& Sakellariou, C. (2006). Estimating the returns to education: accounting for heterogeneity in ability (World Bank Policy Research Working

Paper 4040). Retrieved from the World Bank website: http://documents.worldbank.org

Patrinos, H.A., Ridao-Cano, C. \& Sakellariou, C. (2009). A note on schooling and wage inequality in the public and private sector. Empirical Economics 37. 383-92.

Pereire, Pedro T. \& Martins, Pedro S. (2004). Does education reduce wage inequality? Quantile regression evidence from 16 countries. Labour Economics. 11(3). 355371.

Psacharopoulos, G. (1985). Returns to education: a further international update and implications. The Journal of Human Resources 20 (4).583-604.

Psacharopoulos, G. (1994). Returns to investment in education: a global update. World Development 22 (9). 1325-43. 
Purnastuti, Losina, Miller Paul W., \& Salim, Ruhul. (2013). Declining rates of return to education: evidence for Indonesia. Bulletin of Indonesian Economic Studies. 49(2). 213-236.

Salehatin G., Ebru C. (2011). Returns to education and wages in Turkey: robust and resistant regression. Qual Quant 46.1407-1416.

Sakellariou, C. (2003). Rates of return to investments in formal and technical/vocational education in Singapore. Education Economics 11 (1). 73-87.

Sukma, Weni L. \& Kadir. (2018). Decomposition of the Gender Wage Gap in Indonesia: A Picture from SAKERNAS Data, presented at the Asia-Pacific Research in Social Sciences and Humanities Conference, 2018. Jakarta: Universitas Indonesia.

Suryahadi, Asep, Al Izzati, Ridho \& Suryadarma, Daniel. (2018). the Causes and Consequences of Increasing Inequality in Indonesia: A Long Term View (SMERU Working Paper). Retrieved from SMERU Research Institute website: http://smeru.or.id

Sohn, Kitae. (2015). Gender Discrimination in Earnings in Indonesia: A Fuller Picture, Bulletin ofIndonesian. Economic Studies.51(1).95-121.

Trostel, Philip, Ian Walker, \& Paul Woolley. (2002). Estimates of the economic return to schooling for 28 countries. Labour economics 9(1). 1-16.

Widyanti, Restuning D. (2018). Wage Inequality And Return To Education In Indonesia: Quantile Regression Analysis. Jurnal Ilmu Ekonomi Signifikan. 7(1).27-44. 
Table 1.

Definition of dependent and explanatory variables

\begin{tabular}{|c|c|}
\hline \multicolumn{2}{|c|}{ Dependent variable: logarithmic of monthly (nominal) wages. } \\
\hline Years of schooling & $\begin{array}{l}\text { It is approached with the highest educational attainment that is converted into } \\
\text { years of schooling }\end{array}$ \\
\hline $\begin{array}{l}\text { Educational } \\
\text { attainment }\end{array}$ & $\begin{array}{l}\text { PHD } 1 \text { if the highest qualification is a doctoral degree, } 0 \text { otherwise; Master } \\
1 \text { if the highest qualification is a master degree, } 0 \text { otherwise; Undergraduate } \\
1 \text { if the highest qualification is bachelor degree, } 0 \text { otherwise; Diploma } 1 \text { if } \\
\text { the highest qualification is Diploma, } 0 \text { otherwise; SHS if the highest } \\
\text { qualification is senior high school, } 0 \text { otherwise; JHS if the highest } \\
\text { qualification is junior high school, } 0 \text { otherwise; PS if the highest qualification } \\
\text { is primary high school, } 0 \text { otherwise; NS if the highest qualification is under } \\
\text { primary school or no schooling, } 0 \text { otherwise (reference group). }\end{array}$ \\
\hline Experience & It is a potential experience in years. \\
\hline Experience2 & The squared of potential experience divided by 100 . \\
\hline Tenure & It is measured in years. \\
\hline Tenure2 & The squared of tenure divided by 100 . \\
\hline $\begin{array}{l}\text { Demographic } \\
\text { variables }\end{array}$ & $\begin{array}{l}\text { Female } 1 \text { if an individual is female, } 0 \text { otherwise; Cohort45plus } 1 \text { if an } \\
\text { individual's age is } 45+\text { years old, } 0 \text { otherwise; Married } 1 \text { if the marital status } \\
\text { is married, } 0 \text { otherwise; Urban } 1 \text { if an individual lives in the urban area, } 0 \\
\text { otherwise }\end{array}$ \\
\hline Working hours & $\begin{array}{l}\text { The working hours in a month obtained by multiplying the regular working } \\
\text { hours of the week by four. }\end{array}$ \\
\hline Job training & Training 1 if an individual has been trained before, 0 otherwise. \\
\hline Union membership & Union 1 if an individual is a member of the labour union, 0 otherwise. \\
\hline $\begin{array}{l}\text { Employment status } \\
\text { related to working } \\
\text { hours }\end{array}$ & Full employment 1 if an individual is a full employment, 0 otherwise. \\
\hline Occupation & $\begin{array}{l}\text { Professional } 1 \text { if the occupation is either manager, professional, technicians, } \\
\text { or police/army, } 0 \text { otherwise; Hard-work } 1 \text { if the occupation is doing hard } \\
\text { work, } 0 \text { otherwise. }\end{array}$ \\
\hline $\begin{array}{l}\text { Working under } \\
\text { contract }\end{array}$ & Contract 1 if an individual is working under contract, otherwise. \\
\hline $\begin{array}{l}\text { Number of } \\
\text { household } \\
\text { members }\end{array}$ & $\begin{array}{l}\text { Consisting of two variables: the total number of household members } \\
\text { (households) and the number of household members under } 10 \text { years old } \\
\text { (households10). }\end{array}$ \\
\hline Industry & $\begin{array}{l}\text { The employment sectors consisting of nine categories: agricultural (reference } \\
\text { group); mining, quarrying; manufacturing; gas, electricity, and water; } \\
\text { construction; wholesale, retail, restaurants and hotels; transportation, storage, } \\
\text { and communications; finance, insurance, real estate, and business services; } \\
\text { social services. }\end{array}$ \\
\hline $\begin{array}{l}\text { Dummy variables } \\
\text { for the institution }\end{array}$ & $\begin{array}{l}\text { It consists of eight categories: government (reference group); international } \\
\text { institution/organisation; non-profit institutions; profit institutions; } \\
\text { cooperatives; individual/households business; households; others }\end{array}$ \\
\hline $\begin{array}{l}\text { Dummy variables } \\
\text { for provinces }\end{array}$ & $\begin{array}{l}\text { They are dedicated to taking into account the fixed effect (regional specific } \\
\text { effects). The number of provinces is } 34 \text { provinces. }\end{array}$ \\
\hline
\end{tabular}


JURNAL LITBANG SUKOWATI | VOLUME 2 | NOMOR 2 | TAHUN 2019 | HAL. 12 - 30

Table 2.

The rate of returns to education by educational level

\begin{tabular}{|l|c|c|c|c|c|c|c|}
\hline $\begin{array}{l}\text { Level of } \\
\text { education }\end{array}$ & $\mathrm{q}_{1}$ & $\mathrm{q}_{2}$ & $\mathrm{q}_{4}$ & $\mathrm{q}_{6}$ & $\mathrm{q}_{8}$ & $\mathrm{q}_{9}$ & OLS \\
\hline $\begin{array}{l}\text { Primary } \\
\text { School }\end{array}$ & 0.51 & -0.10 & 0.83 & 0.70 & 0.69 & 0.99 & 0.65 \\
\hline $\begin{array}{l}\text { Junior High } \\
\text { School }\end{array}$ & 1.33 & 1.18 & 1.95 & 1.40 & 1.24 & 1.10 & 0.90 \\
\hline $\begin{array}{l}\text { Senior High } \\
\text { School }\end{array}$ & 2.10 & 2.12 & 2.40 & 1.99 & 1.94 & 2.06 & 1.94 \\
\hline Diploma & 1.61 & 2.16 & 2.56 & 2.62 & 2.33 & 2.65 & 2.74 \\
\hline Undergraduate & 2.84 & 2.71 & 2.94 & 2.98 & 2.74 & 2.98 & 2.65 \\
\hline Master & 3.27 & 2.73 & 3.27 & 3.39 & 3.29 & 3.55 & 3.67 \\
\hline PhD & 6.57 & 5.51 & 6.44 & 4.46 & 4.22 & 4.40 & 4.14 \\
\hline
\end{tabular}


Table 3.

The results of earning equation estimation (pooled sample: years of schooling)

\begin{tabular}{|c|c|c|c|c|c|c|}
\hline & OLS & $\mathrm{q}_{1}$ & $\mathrm{q}_{2}$ & $\mathrm{q}_{8}$ & $\mathrm{q}_{9}$ & $\Delta(\%)$ \\
\hline Female & $\begin{array}{r}-0.2376 * * * \\
(0.0089)\end{array}$ & $\begin{array}{r}-0.2570 * * * \\
(0.0120)\end{array}$ & $\begin{array}{r}-0.2840 * * * \\
(0.0172)\end{array}$ & $\begin{array}{r}-0.1822 * * * \\
(0.0085)\end{array}$ & $\begin{array}{r}-0.1774 * * * \\
(0.0102)\end{array}$ & - \\
\hline Married & $\begin{array}{r}0.0306 * * * \\
(0.0102)\end{array}$ & $\begin{array}{r}0.0318^{* *} \\
(0.0135)\end{array}$ & $\begin{array}{r}0.0161 \\
(0.0185)\end{array}$ & $\begin{array}{r}0.0424 * * * \\
(0.0100)\end{array}$ & $\begin{array}{r}0.0461 * * * \\
(0.0119)\end{array}$ & - \\
\hline Cohort $45+$ & $\begin{array}{r}0.1045^{* * * *} \\
(0.0152)\end{array}$ & $\begin{array}{r}0.0881 * * * \\
(0.0204)\end{array}$ & $\begin{array}{r}0.1021 * * * \\
(0.0280)\end{array}$ & $\begin{array}{r}0.0693 * * * \\
(0.0136)\end{array}$ & $\begin{array}{r}0.0779 * * * \\
(0.0189)\end{array}$ & - \\
\hline Years of schooling & $\begin{array}{r}0.0367 * * * \\
(0.0013)\end{array}$ & $\begin{array}{r}0.0343 * * * \\
(0.0016)\end{array}$ & $\begin{array}{r}0.0340 * * * \\
(0.0026)\end{array}$ & $\begin{array}{r}0.0363 * * * \\
(0.0013)\end{array}$ & $\begin{array}{r}0.0383 * * * \\
(0.0015)\end{array}$ & 0.4 \\
\hline Experience & $\begin{array}{r}0.0195 \\
(0.0012)\end{array}$ & $\begin{array}{r}0.0179 * * * \\
(0.0016)\end{array}$ & $\begin{array}{r}0.0169 * * * \\
(0.0022)\end{array}$ & $\begin{array}{r}0.0156 * * * \\
(0.0011)\end{array}$ & $\begin{array}{r}0.0147 * * * \\
(0.0014)\end{array}$ & - \\
\hline Experience $^{2} / 100$ & $\begin{array}{r}-0.0373 * * * \\
(0.0023)\end{array}$ & $\begin{array}{r}-0.0366^{* * * *} \\
(0.0032)\end{array}$ & $\begin{array}{r}-0.0386 * * * \\
(0.0048)\end{array}$ & $\begin{array}{r}-0.0271 * * * \\
(0.0022)\end{array}$ & $\begin{array}{r}-0.0248 * * * \\
(0.0028)\end{array}$ & - \\
\hline Tenure & $\begin{array}{r}0.0206 * * * \\
(0.0013)\end{array}$ & $\begin{array}{r}0.0184 * * * \\
(0.0017)\end{array}$ & $\begin{array}{r}0.0231 * * * \\
(0.0028)\end{array}$ & $\begin{array}{r}0.0170 * * * \\
(0.0013)\end{array}$ & $\begin{array}{r}0.0166 * * * \\
(0.0015)\end{array}$ & - \\
\hline Tenure $^{2} / 100$ & $\begin{array}{r}-0.0185^{* * * *} \\
(0.0036)\end{array}$ & $\begin{array}{r}-0.0103 * * \\
(0.0050)\end{array}$ & $\begin{array}{r}-0.0219 * * \\
(0.0095)\end{array}$ & $\begin{array}{r}-0.0189 * * * \\
(0.0037)\end{array}$ & $\begin{array}{r}-0.0216 * * * \\
(0.0042)\end{array}$ & - \\
\hline N. of household & $\begin{array}{r}-0.0057 * * \\
(0.0026)\end{array}$ & $\begin{array}{r}-0.0115 * * * \\
(0.0033)\end{array}$ & $\begin{array}{r}-0.0124 * * * \\
(0.0046)\end{array}$ & $\begin{array}{r}-0.0008 * * * \\
(0.0026)\end{array}$ & $\begin{array}{r}0.00002 * * * \\
(0.0030)\end{array}$ & - \\
\hline N. of household under 10 & $\begin{array}{l}0.0097 * \\
(0.0056)\end{array}$ & $\begin{array}{r}0.0083 \\
(0.0076)\end{array}$ & $\begin{array}{r}0.0093 \\
(0.0102)\end{array}$ & $\begin{array}{r}0.0083 \\
(0.0055)\end{array}$ & $\begin{array}{l}0.0133^{*} \\
(0.0068)\end{array}$ & - \\
\hline Urban & $\begin{array}{r}0.0724 * * * \\
(0.0083)\end{array}$ & $\begin{array}{r}0.0735 * * * \\
(0.0110)\end{array}$ & $\begin{array}{r}0.0840 * * * \\
(0.0157)\end{array}$ & $\begin{array}{r}0.0292 * * * \\
(0.0083)\end{array}$ & $\begin{array}{r}0.0177 * * * \\
(0.0090)\end{array}$ & - \\
\hline Full employment & $\begin{array}{r}0.4252 * * * \\
(0.0159)\end{array}$ & $\begin{array}{r}0.6408 * * * \\
(0.0235)\end{array}$ & $\begin{array}{r}0.6889 * * * \\
(0.0280)\end{array}$ & $\begin{array}{r}0.2711 * * * \\
(0.0153)\end{array}$ & $\begin{array}{r}0.2238 * * * \\
(0.0171)\end{array}$ & - \\
\hline Working hours & $\begin{array}{r}0.0019 * * * \\
(0.0001)\end{array}$ & $\begin{array}{r}0.0014 * * * \\
(0.0001)\end{array}$ & $\begin{array}{r}0.0015 * * * \\
(0.0002)\end{array}$ & $\begin{array}{r}0.0018 * * * \\
(0.0001)\end{array}$ & $\begin{array}{r}0.0017 * * * \\
(0.0001)\end{array}$ & - \\
\hline Job training & $\begin{array}{r}0.2256 * * * \\
(0.0123)\end{array}$ & $\begin{array}{r}0.2074 * * * \\
(0.0158)\end{array}$ & $\begin{array}{r}0.1946 * * * \\
(0.0193)\end{array}$ & $\begin{array}{r}0.1893 * * * \\
(0.0112)\end{array}$ & $\begin{array}{r}0.1921 * * * \\
(0.0156)\end{array}$ & - \\
\hline Union membership & $\begin{array}{r}0.2108 * * * \\
(0.0130)\end{array}$ & $\begin{array}{r}0.2452 * * * \\
(0.0151)\end{array}$ & $\begin{array}{r}0.2200 * * * \\
(0.0230)\end{array}$ & $\begin{array}{r}0.1465 * * * \\
(0.0118)\end{array}$ & $\begin{array}{r}0.1384 * * * \\
(0.0154)\end{array}$ & - \\
\hline Employment status & $\begin{array}{r}0.0809 * * * \\
(0.0123)\end{array}$ & $\begin{array}{r}0.1059 * * * \\
(0.0162)\end{array}$ & $\begin{array}{r}0.1315 * * * \\
(0.0237)\end{array}$ & $\begin{array}{r}0.0568 * * * \\
(0.0115)\end{array}$ & $\begin{array}{r}0.0581 * * * \\
(0.0132)\end{array}$ & - \\
\hline Working under contract & $\begin{array}{r}0.1280 * * * \\
(0.0093)\end{array}$ & $\begin{array}{r}0.1383 * * * \\
(0.0118)\end{array}$ & $\begin{array}{r}0.14670 \text { *** } \\
(0.0169)\end{array}$ & $\begin{array}{r}0.1094 * * * \\
(0.0095)\end{array}$ & $\begin{array}{r}0.1151 * * * \\
(0.0102)\end{array}$ & - \\
\hline Professional & $\begin{array}{r}-0.0595 * * * \\
(0.0090)\end{array}$ & $\begin{array}{r}-0.0485 * * * \\
(0.0119)\end{array}$ & $\begin{array}{r}-0.0446 * * \\
(0.0179)\end{array}$ & $\begin{array}{r}-0.0963 * * * \\
(0.0091)\end{array}$ & $\begin{array}{r}-0.1003 * * * \\
(0.0130)\end{array}$ & \\
\hline Hard-Work & $\begin{array}{r}0.1557 * * * \\
(0.0144)\end{array}$ & $\begin{array}{r}0.0518 * * \\
(0.0221)\end{array}$ & $\begin{array}{r}-0.0192 \\
(0.0246)\end{array}$ & $\begin{array}{r}0.3013 * * * \\
(0.0135)\end{array}$ & $\begin{array}{r}0.3625 * * * \\
(0.0181)\end{array}$ & \\
\hline $\begin{array}{l}\text { Dummy: industry; } \\
\text { institution; provinces }\end{array}$ & - & - & - & - & - & - \\
\hline Number of observations & 36,339 & 36,339 & 36,339 & 36,339 & 36,339 & \\
\hline
\end{tabular}

Note: Sampling weights are applied. Robust standard errors are in the parentheses. ${ }^{*} \mathrm{p}=0.10$;

$* * \mathrm{p}=0.05 ; * * \mathrm{p}=0.01 . \Delta=\left(q_{9}-q_{1}\right) \times 100 \%$. 
Table 4.

The results of earning equation estimation (pooled sample: level of education)

\begin{tabular}{|c|c|c|c|c|c|c|}
\hline & OLS & $\mathrm{q}_{1}$ & $\mathrm{q}_{2}$ & $\mathrm{q}_{8}$ & $\mathrm{q}_{9}$ & $\Delta(\%)$ \\
\hline \multirow[t]{2}{*}{ Female } & $-0.2539 * * *$ & $-0.2788 * * *$ & $-0.2694 * * *$ & $-0.1999 * * *$ & $-0.2033 * * *$ & - \\
\hline & $(0.0090)$ & $(0.0137)$ & $(0.0125)$ & $(0.0081)$ & $(0.0100)$ & \\
\hline \multirow[t]{2}{*}{ Married } & $0.0326 * * *$ & $0.0267 * * *$ & $0.0301 * * *$ & $0.0489 * * *$ & $0.0582 * * *$ & - \\
\hline & $(0.0101)$ & $(0.0157)$ & $(0.0133)$ & $(0.0092)$ & $(0.0118)$ & \\
\hline \multirow[t]{2}{*}{ Cohort 45+ } & $0.1011 * * *$ & $0.0906 * * *$ & $0.0696 * *$ & $0.0827 * * *$ & $0.0995 * * *$ & - \\
\hline & $(0.0151)$ & $(0.0207)$ & $(0.0196)$ & $(0.0135)$ & $(0.0139)$ & \\
\hline \multirow[t]{2}{*}{ Primary School } & $0.0307 * *$ & -0.0058 & $0.0496 * * *$ & $0.0591 * * *$ & $0.0391 *$ & 4.49 \\
\hline & $(0.0147)$ & $(0.0224)$ & $(0.0177)$ & $(0.0145)$ & $(0.023)$ & \\
\hline \multirow[t]{2}{*}{ Junior High School } & $0.1199 * * *$ & $0.1066 * * *$ & $0.17520 * * *$ & $0.0987 * * *$ & $0.0811 * * *$ & -2.55 \\
\hline & $(0.0165)$ & $(0.0255)$ & $(0.0185)$ & $(0.0163)$ & $(0.0242)$ & \\
\hline \multirow[t]{2}{*}{ Senior High School } & $0.2517 * * *$ & $0.2548 * * *$ & $0.2882 * * *$ & $0.2477 * * *$ & $0.2328 * * *$ & -2.20 \\
\hline & $(0.0174)$ & $(0.0237)$ & $(0.0193)$ & $(0.0165)$ & $(0.0244)$ & \\
\hline \multirow[t]{2}{*}{ Diploma } & $0.3412 * * *$ & $0.3128 * * *$ & $0.3707 * * *$ & $0.3838 * * *$ & $0.3974 * * *$ & 8.46 \\
\hline & $(0.0441)$ & $(0.0579)$ & $(0.0891)$ & $(0.0286)$ & $(0.0525)$ & \\
\hline \multirow{2}{*}{ Undergraduate } & $0.4536 * * *$ & $0.4335 * * *$ & $0.4699 * * *$ & $0.4774 * * *$ & $0.4241 * * *$ & -0.94 \\
\hline & $(0.0301)$ & $(0.0328)$ & $(0.0416)$ & $(0.0211)$ & $(0.0424)$ & \\
\hline \multirow[t]{2}{*}{ Master } & $0.5890 * * *$ & $0.4916^{* * *}$ & $0.5889 * * *$ & $0.6384 * * *$ & $0.6609 * * *$ & 16.93 \\
\hline & $(0.0242)$ & $(0.0314)$ & $(0.0312)$ & $(0.0233)$ & $(0.0302)$ & \\
\hline \multirow[t]{2}{*}{$\mathrm{PhD}$} & $1.0445 * * *$ & $1.2124 * * *$ & $1.1416 * * *$ & $0.9682 * * *$ & $0.9108 * * *$ & -30.16 \\
\hline & $(0.0396)$ & $(0.0534)$ & $(0.0576)$ & $(0.0438)$ & $(0.0330)$ & \\
\hline \multirow[t]{2}{*}{ Experience } & $0.0217 * * *$ & $0.0205 * * *$ & $0.0201 * * *$ & $0.0176^{* * *}$ & $0.0151 * * *$ & - \\
\hline & $(0.0012)$ & (0.0019) & $(0.0015)$ & $(0.0011)$ & $(0.0013)$ & \\
\hline \multirow[t]{2}{*}{ Experience $^{2} / 100$} & $-0.0438 * * *$ & $-0.0455^{* * *}$ & $-0.0403 * * *$ & $-0.0345 * * *$ & $-0.0303 * * *$ & - \\
\hline & $(0.0023)$ & $(0.0038)$ & $(0.0029)$ & $(0.0023)$ & $(0.0025)$ & \\
\hline \multirow[t]{2}{*}{ Tenure } & $0.0198 * * *$ & $0.0216 * * *$ & $0.0174 * * *$ & $0.0161 * * *$ & $0.0155 * * *$ & - \\
\hline & $(0.0013)$ & $(0.0022)$ & $(0.0019)$ & $(0.0012)$ & $(0.0015)$ & \\
\hline \multirow[t]{2}{*}{ Tenure $^{2} / 100$} & $-0.0156 * * *$ & $-0.0194 * * *$ & -0.0090 & $-0.0151 * * *$ & $-0.0150 * * *$ & - \\
\hline & $(0.0035)$ & $(0.0071)$ & $(0.0062)$ & $(0.0034)$ & $(0.0050)$ & \\
\hline \multirow[t]{2}{*}{ N. of household } & $-0.0059 * *$ & $-0.0082 * *$ & $-0.0099 * * *$ & -0.0036 & -0.0010 & - \\
\hline & $(0.0026)$ & $(0.0037)$ & $(0.0031)$ & $(0.0024)$ & $(0.0026)$ & \\
\hline \multirow[t]{2}{*}{ N. of household under 10} & 0.0082 & 0.0021 & $0.0101 * * *$ & 0.0084 & 0.0090 & - \\
\hline & $(0.0055)$ & $(0.0090)$ & $(0.0071)$ & $(0.0054)$ & $(0.0057)$ & \\
\hline \multirow[t]{2}{*}{ Urban } & $0.0678 * * *$ & $0.0810 * * *$ & $0.0688 * * *$ & $0.0203 * * *$ & $0.0228 * * *$ & - \\
\hline & $(0.0083)$ & $(0.0136)$ & $(0.0104)$ & $(0.0078)$ & $(0.0082)$ & \\
\hline \multirow[t]{2}{*}{ Full employment } & $0.4124 * * *$ & $0.6822 * * *$ & $0.6152 * * *$ & $0.2648 * * *$ & $0.2137 * * *$ & - \\
\hline & $(0.0158)$ & $(0.0252)$ & $(0.0234)$ & $(0.0139)$ & $(0.0159)$ & \\
\hline \multirow[t]{2}{*}{ Working hours } & $0.0020 * * *$ & $0.0015 * * *$ & $0.0015^{* * *}$ & $0.0019 * * *$ & $0.0019 * * *$ & - \\
\hline & $(0.0001)$ & $(0.0001)$ & $(0.0001)$ & $(0.0001)$ & $(0.0001)$ & \\
\hline \multirow[t]{2}{*}{ Job training } & $0.1887 * * *$ & $0.1686 * * *$ & $0.1726 * * *$ & $0.1276^{* * *}$ & $0.1410 * * *$ & - \\
\hline & $(0.0124)$ & $(0.0143)$ & $(0.0149)$ & $(0.0111)$ & $(0.0107)$ & \\
\hline \multirow[t]{2}{*}{ Union membership } & $0.1926 * * *$ & $0.2179 * * *$ & $0.2261 * * *$ & $0.1350 * * *$ & $0.1244 * * *$ & - \\
\hline & $(0.0130)$ & $(0.0194)$ & $(0.0179)$ & $(0.0111)$ & $(0.0131)$ & \\
\hline \multirow[t]{2}{*}{ Employment status } & $0.0918 * * *$ & $0.1172 * * *$ & $0.1168 * * *$ & $0.0704 * * *$ & $0.0661 * * *$ & - \\
\hline & $(0.0123)$ & $(0.0204)$ & $(0.0147)$ & $(0.0114)$ & $(0.0111)$ & \\
\hline Working under contract & $0.1272 * * *$ & $0.1500 * * *$ & $0.1365 * * *$ & $0.1111 * * *$ & $0.1085 * * *$ & - \\
\hline & $(0.0093)$ & $(0.0141)$ & $(0.0110)$ & $(0.0089)$ & $(0.0103)$ & \\
\hline $\begin{array}{l}\text { Dummy: occupation, industry; } \\
\text { institution; provinces }\end{array}$ & - & - & - & - & - & - \\
\hline
\end{tabular}

\begin{tabular}{lllllll}
\hline Number of observations & 36,339 & 36,339 & 36,339 & 36,339 & 36,339 & 36,339 \\
\hline
\end{tabular}

Note: Sampling weights are applied. Robust standard errors are in the parentheses. ${ }^{*} \mathrm{p}=0.10$; $* * \mathrm{p}=0.05 ; * * * \mathrm{p}=0.01 . \Delta=\left(q_{9}-q_{1}\right) \times 100 \%$. 
Table 5.

The results of earning equation estimation (gender group: years of schooling)

\begin{tabular}{|c|c|c|c|c|c|c|}
\hline & \multicolumn{3}{|c|}{ Male } & \multicolumn{3}{|c|}{ Female } \\
\hline & OLS & $\mathrm{q}_{1}$ & $\mathrm{q}_{9}$ & OLS & $\mathrm{q}_{1}$ & $\mathrm{q}_{9}$ \\
\hline \multirow[t]{2}{*}{ Married } & $0.1083 * * *$ & $0.1219 * *$ & $0.1045 * * *$ & $-0.0336 * *$ & 0.0784 & -0.0393 \\
\hline & $(0.0127)$ & $(0.0540)$ & $(0.0200)$ & $(0.0169)$ & $(0.0691)$ & $(0.0256)$ \\
\hline \multirow[t]{2}{*}{ Cohort $45+$} & $0.0698 * * *$ & $0.1424 *$ & $0.0573 *$ & $0.1800 * * *$ & $0.2810 * *$ & $0.1970 * * *$ \\
\hline & $(0.0175)$ & $(0.0816)$ & $(0.0305)$ & $(0.0288)$ & $(0.1119)$ & $(0.0477)$ \\
\hline \multirow[t]{2}{*}{ Years of schooling } & $0.0311 * * *$ & $0.0211 * * *$ & $0.0327 * * *$ & $0.0491 * * *$ & $0.0499 * * *$ & $0.0463 * * *$ \\
\hline & $(0.0015)$ & $(0.0060)$ & $(0.0027)$ & $(0.0028)$ & $(0.0096)$ & $(0.0040)$ \\
\hline \multirow[t]{2}{*}{ Experience } & $0.0185 * * *$ & 0.0080 & $0.0178 * * *$ & $0.0211 * * *$ & -0.0127 & $0.0125 * * *$ \\
\hline & $(0.0014)$ & $(0.0072)$ & $(0.0023)$ & $(0.0020)$ & $(0.0096)$ & $(0.0033)$ \\
\hline \multirow[t]{2}{*}{ Experience $^{2} / 100$} & $-0.0361 * * *$ & $-0.0321 * * *$ & $-0.0397 * * *$ & $-0.0380 * * *$ & -0.0181 & $-0.0301 * * *$ \\
\hline & $(0.0027)$ & $(0.0122)$ & $(0.0050)$ & $(0.0040)$ & $(0.0261)$ & $(0.0085)$ \\
\hline \multirow[t]{2}{*}{ Tenure } & $0.0174 * * *$ & $0.0355 * * *$ & $0.0234 * * *$ & $0.0263 * * *$ & $0.0676 * * *$ & $0.0233 * * *$ \\
\hline & $(0.0015)$ & $(0.0072)$ & $(0.0027)$ & $(0.0027)$ & $(0.0105)$ & $(0.0040)$ \\
\hline \multirow[t]{2}{*}{ Tenure $^{2} / 100$} & $-0.0159 * * *$ & $-0.0744 * * *$ & $-0.0300 * * *$ & $-0.0255 * * *$ & $-0.1183 * * *$ & -0.0073 \\
\hline & $(0.0041)$ & $(0.0224)$ & $(0.0094)$ & $(0.0069)$ & $(0.0318)$ & $(0.0123)$ \\
\hline \multirow[t]{2}{*}{ N. of household } & $-0.0077 * * *$ & -0.0077 & $-0.0121 * *$ & -0.0003 & -0.0276 & 0.0028 \\
\hline & $(0.0030)$ & $(0.0122)$ & $(0.0049)$ & $(0.0048)$ & $(0.0199)$ & $(0.0069)$ \\
\hline \multirow[t]{2}{*}{ N. of household under 10} & 0.0022 & -0.0355 & -0.0025 & 0.0143 & 0.0265 & 0.0021 \\
\hline & $(0.0064)$ & $(0.0271)$ & $(0.0106)$ & $(0.0106)$ & $(0.0447)$ & $(0.0168)$ \\
\hline \multirow[t]{2}{*}{ Urban } & $0.0578 * * *$ & 0.0647 & $0.0722 * * *$ & $0.1098 * * *$ & $0.1771 * * *$ & $0.0911 * * *$ \\
\hline & $(0.0093)$ & $(0.0409)$ & $(0.0169)$ & $(0.0165)$ & $(0.0533)$ & $(0.0245)$ \\
\hline \multirow[t]{2}{*}{ Full employment } & $0.3921 * * *$ & $0.9727 * * *$ & $0.6860 * * *$ & $0.3895^{* * *}$ & $0.3473 * * *$ & $0.5916 * * *$ \\
\hline & $(0.0198)$ & $(0.0827)$ & $(0.0418)$ & $(0.0261)$ & $(0.0873)$ & $(0.0386)$ \\
\hline \multirow[t]{2}{*}{ Working hours } & $0.0015^{* * *}$ & $0.0014 * *$ & $0.0009 * * *$ & $0.0028 * * *$ & $0.0053 * * *$ & $0.0027 * * *$ \\
\hline & $(0.0001)$ & $(0.0006)$ & $(0.0002)$ & $(0.0002)$ & $(0.0008)$ & $(0.0002)$ \\
\hline \multirow[t]{2}{*}{ Job training } & $0.2026 * * *$ & $0.2828 * * *$ & $0.1634 * * *$ & $0.2457 * * *$ & $0.2356 * * *$ & $0.2407 * * *$ \\
\hline & $(0.0145)$ & $(0.0525)$ & $(0.0171)$ & $(0.0216)$ & $(0.0781)$ & $(0.0280)$ \\
\hline \multirow[t]{2}{*}{ Union membership } & $0.1426 * * *$ & $0.1200 * *$ & $0.1662 * * *$ & $0.3023 * * *$ & $0.2791 * * *$ & $0.3163 * * *$ \\
\hline & $(0.0151)$ & $(0.0553)$ & $(0.0192)$ & $(0.0233)$ & $(0.1054)$ & $(0.0350)$ \\
\hline \multirow[t]{2}{*}{ Employment status } & $0.0608 * * *$ & -0.0260 & $0.0762 * * *$ & $0.1660 * * *$ & $0.2996 * *$ & $0.3155 * * *$ \\
\hline & $(0.0130)$ & $(0.0580)$ & $(0.0218)$ & $(0.0303)$ & $(0.1243)$ & $(0.0544)$ \\
\hline \multirow[t]{2}{*}{ Working under contract } & $0.1131^{* * *}$ & $0.0960 * *$ & $0.1432 * * *$ & $0.1464 * * *$ & $0.2146 * * *$ & $0.1772 * * *$ \\
\hline & $(0.0104)$ & $(0.0468)$ & $(0.0155)$ & $(0.0186)$ & $(0.0785)$ & $(0.0212)$ \\
\hline $\begin{array}{l}\text { Dummy: occupation, industry; } \\
\text { institution; provinces }\end{array}$ & - & - & - & - & - & - \\
\hline Number of observations & 24,176 & 12,163 & 24,176 & 12,163 & 24,176 & 12,163 \\
\hline
\end{tabular}

Note: Sampling weights are applied. Robust standard errors are in the parentheses. ${ }^{*} p=0.10$;

$* * \mathrm{p}=0.05 ; * * * \mathrm{p}=0.01$. 
Table 6.

The results of earning equation estimation (gender group: level of education)

\begin{tabular}{|c|c|c|c|c|c|c|}
\hline & \multicolumn{3}{|c|}{ Male } & \multicolumn{3}{|c|}{ Female } \\
\hline & OLS & $\mathrm{q}_{1}$ & $\mathrm{q}_{9}$ & OLS & $\mathrm{q}_{1}$ & $\mathrm{q}_{9}$ \\
\hline \multirow[t]{2}{*}{ Married } & $0.1083 * * *$ & $0.1616 * * *$ & $0.0889 * * *$ & $-0.0343 * *$ & 0.0838 & $-0.0544 * * *$ \\
\hline & $(0.0126)$ & $(0.0602)$ & $(0.0212)$ & $(0.0168)$ & $(0.0871)$ & (0.0196) \\
\hline \multirow[t]{2}{*}{ Cohort 45+ } & $0.0631 * * *$ & 0.1262 & 0.0319 & $0.1778 * * *$ & $0.2112 *$ & $0.1889 * * *$ \\
\hline & $(0.0173)$ & $(0.0768)$ & $(0.0266)$ & $(0.0286)$ & $(0.1254)$ & $(0.0382)$ \\
\hline \multirow[t]{2}{*}{ Primary School } & 0.0274 & $0.1521 *$ & 0.0216 & 0.0187 & $-0.3363 * * *$ & -0.0101 \\
\hline & $(0.0168)$ & $(0.0832)$ & $(0.0372)$ & $(0.0296)$ & $(0.1028)$ & $(0.0415)$ \\
\hline \multirow[t]{2}{*}{ Junior High School } & $0.0889 * * *$ & $0.2312 * * *$ & $0.1021 * * *$ & $0.1906 * * *$ & -0.0344 & $0.2017 * * *$ \\
\hline & $(0.0184)$ & $(0.0869)$ & $(0.0371)$ & $(0.0349)$ & $(0.1350)$ & $(0.0441)$ \\
\hline \multirow[t]{2}{*}{ Senior High School } & $0.2091 * * *$ & $0.2406 * *$ & $0.2683 * * *$ & $0.3817 * * *$ & 0.1991 & $0.3541 * * *$ \\
\hline & $(0.0194)$ & $(0.0963)$ & $(0.0378)$ & $(0.0373)$ & $(0.1407)$ & $(0.0493)$ \\
\hline \multirow[t]{2}{*}{ Diploma } & $0.3575 * * *$ & $0.6190 * * *$ & $0.4410 * *$ & $0.4143 * * *$ & -0.3669 & $0.2541 * *$ \\
\hline & $(0.0525)$ & $(0.2089)$ & $(0.1768)$ & $(0.0745)$ & $(0.4347)$ & $(0.1262)$ \\
\hline \multirow[t]{2}{*}{ Undergraduate } & $0.3524 * * *$ & $0.5610 * * *$ & $0.4077 * * *$ & $0.6278 * * *$ & 0.0712 & $0.6183 * * *$ \\
\hline & $(0.0380)$ & $(0.1429)$ & $(0.0468)$ & $(0.0530)$ & $(0.2039)$ & $(0.0899)$ \\
\hline \multirow[t]{2}{*}{ Master } & $0.5186 * * *$ & $0.2649 * *$ & $0.4610 * * *$ & $0.7294 * * *$ & $0.3790 * *$ & $0.6626 * * *$ \\
\hline & $(0.0287)$ & $(0.1218)$ & $(0.0516)$ & $(0.0479)$ & $(0.1524)$ & $(0.0614)$ \\
\hline \multirow[t]{2}{*}{$\mathrm{PhD}$} & $0.9678 * * *$ & $1.4239 * * *$ & $1.1858 * * *$ & $1.1773 * * *$ & $1.4173 * * *$ & $1.4135^{* * * *}$ \\
\hline & $(0.0494)$ & $(0.2524)$ & $(0.0596)$ & $(0.0684)$ & $(0.3186)$ & $(0.1009)$ \\
\hline \multirow[t]{2}{*}{ Experience } & $0.0201 * * *$ & 0.0050 & $0.0207 * * *$ & $0.0255 * * *$ & -0.0000 & $0.0198 * * *$ \\
\hline & $(0.0014)$ & $(0.0076)$ & $(0.0024)$ & $(0.0021)$ & $(0.0110)$ & $(0.0028)$ \\
\hline \multirow[t]{2}{*}{ Experience $^{2} / 100$} & $-0.0405 * * *$ & $-0.0210 * *$ & $-0.0433 * * *$ & $-0.0503 * * *$ & -0.0479 & $-0.0469 * * *$ \\
\hline & $(0.0027)$ & $(0.0144)$ & $(0.0048)$ & $(0.0042)$ & $(0.0301)$ & $(0.0062)$ \\
\hline \multirow[t]{2}{*}{ Tenure } & $0.0169 * * *$ & $0.0365 * * *$ & $0.0226 * * *$ & $0.0249 * * *$ & $0.0425 * * *$ & $0.0223 * * *$ \\
\hline & $(0.0014)$ & $(0.0054)$ & $(0.0024)$ & $(0.0026)$ & $(0.0117)$ & $(0.0037)$ \\
\hline \multirow[t]{2}{*}{ Tenure $^{2} / 100$} & $-0.0143 * * *$ & $-0.0729 * * *$ & $-0.0288 * * *$ & $-0.0205 * * *$ & -0.0432 & -0.0076 \\
\hline & $(0.0040)$ & $(0.0114)$ & $(0.0081)$ & $(0.0068)$ & $(0.0404)$ & $(0.0131)$ \\
\hline \multirow[t]{2}{*}{ N. of household } & $-0.0084 * * *$ & -0.0084 & $-0.0136 * * *$ & 0.0005 & -0.0098 & 0.0006 \\
\hline & $(0.0029)$ & $(0.0145)$ & $(0.0051)$ & $(0.0048)$ & $(0.0208)$ & $(0.0059)$ \\
\hline \multirow[t]{2}{*}{ N. of household under 10} & 0.0017 & -0.0318 & 0.0052 & 0.0102 & -0.0626 & 0.0058 \\
\hline & $(0.0063)$ & $(0.0294)$ & $(0.0097)$ & $(0.0105)$ & $(0.0467)$ & $(0.0128)$ \\
\hline \multirow[t]{2}{*}{ Urban } & $0.0563 * * *$ & $0.0808 * *$ & $0.0791 * * *$ & $0.0969 * * *$ & $0.1445^{* *}$ & $0.1006 * * *$ \\
\hline & $(0.0093)$ & $(0.0403)$ & $(0.0145)$ & $(0.0165)$ & $(0.0615)$ & $(0.0248)$ \\
\hline \multirow[t]{2}{*}{ Full employment } & $0.3822 * * *$ & $0.9815^{* * *}$ & $0.6779 * * *$ & $0.3738 * * *$ & $0.4102 * * *$ & $0.5625 * * *$ \\
\hline & $(0.0197)$ & $(0.0810)$ & $(0.0407)$ & $(0.0260)$ & $(0.4102)$ & $(0.0396)$ \\
\hline \multirow[t]{2}{*}{ Working hours } & $0.0016 * * *$ & $0.0012 * *$ & $0.0010 * * *$ & $0.0028 * * *$ & $0.0046 * * *$ & $0.0028 * * *$ \\
\hline & $(0.0001)$ & $(0.0006)$ & $(0.0002)$ & $(0.0002)$ & $(0.0007)$ & $(0.0002)$ \\
\hline \multirow[t]{2}{*}{ Job training } & $0.1661 * * *$ & $0.2339 * * *$ & $0.1448 * * *$ & $0.2122 * * *$ & $0.2246 * * *$ & $0.1998 * * *$ \\
\hline & $(0.0147)$ & $(0.0608)$ & $(0.0203)$ & $(0.0216)$ & $(0.0776)$ & $(0.0303)$ \\
\hline Union membership & $0.1233 * * *$ & 0.1073 & $0.1545^{* * *}$ & $0.2878 * * *$ & $0.2392 * *$ & $0.2962 * * *$ \\
\hline & $(0.0151)$ & $(0.0722)$ & $(0.0259)$ & $(0.0232)$ & $(0.1133)$ & $(0.0276)$ \\
\hline Employment status & $0.0696 * * *$ & -0.0067 & $0.0541 * *$ & $0.1770 * * *$ & $0.4778 * * *$ & $0.3086 * * *$ \\
\hline & $(0.0130)$ & $(0.0608)$ & $(0.0240)$ & $(0.0303)$ & $(0.1086)$ & $(0.0504)$ \\
\hline Working under contract & $0.1130 * * *$ & $0.1232 * * *$ & $0.1326 * * *$ & $0.1413 * * *$ & $0.2145 * * *$ & 0.1661 \\
\hline & $(0.0103)$ & $(0.0452)$ & $(0.0147)$ & $(0.0186)$ & $(0.0665)$ & $(0.0207)$ \\
\hline Dummy: occupation, & & & & & & \\
\hline institution; provinces & - & - & - & - & - & - \\
\hline Number of observations & 24,176 & 12,163 & 24,176 & 12,163 & 24,176 & 12,163 \\
\hline
\end{tabular}

Note: Sampling weights are applied. Robust standard errors are in the parentheses. ${ }^{*} \mathrm{p}=0.10$; $* * \mathrm{p}=0.05 ; * * * \mathrm{p}=0.01$. 